\title{
The use of hormones to regulate the utilization of nutrients in farm animals: Current farm practices
}

\section{By R. J. Heitzman, Agricultural Research Council, Institute for Research on Animal Diseases, Compton, Newbury, Berkshire RG 16 oNN}

Anabolic agents are used in farm animals to increase the rate of nitrogen retention and protein deposition. There is an increased live weight gain and an improved over-all feed conversion efficiency (FCE) resulting in a more efficient production of meat.

The use of anabolic agents to promote the growth of livestock is not new. Most anabolic agents have functional properties similar to those of the sex steroids, the androgens, oestrogens and progestins, and it was the development of some derivatives of stilbene as cheap synthetic oestrogens which resulted in the initial use in the early 1950 s of these compounds for growth promotion. However, the potential health hazards associated with the use of some stilbene derivatives, especially diethylstilboestrol (DES), were recognized and during the 1970 several countries banned the use of these drugs. This resulted in an intensive search by industry for alternatives, and now although the cost of production of natural steroids like testosterone, oestradiol and progesterone permits their use, several new synthetic steroids like trenbolone acetate and melengestrol acetate have been developed. Another compound, zeranol, a resorcyclic acid lactone with oestrogenlike activity is also widely used.

Anabolic agents may be administered orally or parenterally. Apart from pigs their use as feed additives is not recommended and is often excluded by legislation. Several anabolic agents are available in oil solutions as preparations for intramuscular injection. Some stilbene derivatives are administered by this route to veal calves but their action is only for a short period and with steroid preparations the cost of repeated treatment is so high that this method in farm animals is used only for therapeutic reasons. In practice they are usually given as subcutaneous implants at the base of the ear. It is important from a public health aspect that implants are placed in the correct implant site at the base of the ear, so that after slaughter any residues of the implant in the tissue immediately surrounding the implant may be disposed of.

\section{Use in cattle}

Anabolic agents have been most successfully used in cattle and particularly in intensive rearing systems. They are widely used for veal production in Western Europe and for beef production in the United Kingdom and the Americas. In the UK it is estimated that $10-20 \%$ of beef cattle, mainly steers but some heifers, are 
being implanted with a variety of products. When anabolic agents are used in the appropriate manner there are improvements of about $15 \%$ in growth rate and about $10 \%$ in FCE.

A hypothesis for the role of sex steroids in the growth rate of cattle suggested that both androgens and oestrogens were necessary to realize the maximum growth rate in cattle (Heitzman, 1976). In practice the best responses in growth rate are obtained when androgens are used in females and androgens combined with oestrogens are administered to steers. The latter case is demonstrated by the results shown in Tables $I$ and 2 . Steers treated with anabolic steroids grew at faster rates than the control animals, however, the response to the synthetic androgen, trenbolone acetate was smaller than the response to an oestrogen. When the androgen was combined with oestrogen, the maximum response in growth rate was observed. In a more detailed study (Table 3 ) heifers and steers were implanted with anabolic steroids and there was a significant improvement in FCE as well as growth rate. The animals in this study were fed according to body weights.

\section{Table 1. Performance of steers implanted with anabolic steroids}

$\begin{array}{lrccc}\text { Treatment } & \begin{array}{c}\text { Dose } \\ (\mathrm{mg})\end{array} & \begin{array}{c}\text { No. of } \\ \text { steers }\end{array} & \begin{array}{c}\text { Initial weight } \\ (\mathrm{kg})\end{array} & \begin{array}{c}\text { ADLG for 64 d } \\ (\mathrm{kg} / \mathrm{d})\end{array} \\ \text { Control } & 0 & 15 & 356 & 0.84 \\ \text { TBA } & 300 & 15 & 358 & 0.91 \\ \text { Hexoestrol } & 36 & 15 & 359 & 0.94 \\ \text { TBA + } & 300 & 15 & 349 & 1.17^{*} \\ \text { hexoestrol } & 36 & & & \end{array}$

$-P<0.05$ compared with control.

TBA is trenbolone acetate.

ADLG is a verage daily live weight gain over $64 \mathrm{~d}$ period after implant.

Sussex steers were housed in a feedlot and given $3 \mathrm{~kg}$ concentrates/d and maize silage ad lib.

Results from Heitzman, Harwood et al. (1977).

Table 2. The implantation of steers with anabolic agents

\begin{tabular}{|c|c|c|c|}
\hline Treatment & $\underset{(\mathrm{kg} / \mathrm{d})}{\mathrm{ADLG}}$ & $\begin{array}{c}\text { Cost of } \\
\text { treatment }(\varnothing)\end{array}$ & $\begin{array}{c}\text { Net } \\
\text { benefit }(\ell)\end{array}$ \\
\hline $\begin{array}{l}\text { Control } \\
\text { TBA (300 mg) }\end{array}$ & $\begin{array}{l}0.79 \\
0.86\end{array}$ & $\begin{array}{l}0 \\
1 \cdot 29\end{array}$ & $\begin{array}{l}0 \\
4 \cdot 17\end{array}$ \\
\hline Zeranol ( $36 \mathrm{mg}$ ) & 0.91 & 0.90 & $8 \cdot 46$ \\
\hline Hexoestrol (6o mg) & 0.99 & 0.05 & 15.55 \\
\hline $\begin{array}{l}\text { TBA (300 mg) + } \\
\text { hexoestrol (45 mg) }\end{array}$ & 1.05 & $1 \cdot 33$ & 18.95 \\
\hline
\end{tabular}

Results from Stollard, R. J., Kilkenny, J. B., Mathieson, A. A., Stark, J. S., Taylor, B. R., Sutherland, J. E. \& Williamson, J. T. (unpublished results).

The evaluations were made over a $120 \mathrm{~d}$ period during the fattening period.

TBA is trenbolone acetate.

ADLG is average daily live weight gain.

I 557 steers were used at 13 farms. 
Table 3. Performance of steers and heifers implanted with anabolic steroids

\begin{tabular}{|c|c|c|c|c|c|}
\hline Sex & $\begin{array}{c}\text { No. of } \\
\text { animals }\end{array}$ & $\begin{array}{c}\text { Steroid } \\
\text { implant }\end{array}$ & $\begin{array}{l}\text { Period } \\
\text { (d) }\end{array}$ & $\begin{array}{c}\text { Average daily } \\
\text { gain }(\mathbf{k g})\end{array}$ & FCR \\
\hline $\begin{array}{l}\text { Steer } \\
\text { Steer }\end{array}$ & $\begin{array}{l}4 \\
3\end{array}$ & $\begin{array}{l}\text { None } \\
\text { TBA }\end{array}$ & $\begin{array}{l}63 \\
63\end{array}$ & $\begin{array}{l}0.86 \mathrm{ab} \\
1.02 \mathrm{~b}\end{array}$ & $\begin{array}{c}10.2 \mathrm{~d} \\
9.2\end{array}$ \\
\hline Steer & 4 & $\begin{array}{c}\text { TBA + } \\
\text { oestradiol }\end{array}$ & 63 & $1 \cdot 23^{2}$ & $7 \cdot 4^{d}$ \\
\hline $\begin{array}{l}\text { Heifer } \\
\text { Heifer }\end{array}$ & $\begin{array}{l}6 \\
6\end{array}$ & $\begin{array}{l}\text { None } \\
\text { TBA }\end{array}$ & $\begin{array}{l}5^{6} \\
5^{6}\end{array}$ & $\begin{array}{l}0.65^{c} \\
I \cdot I I C\end{array}$ & $\begin{array}{r}13.9 e \\
8.5 \mathrm{e}\end{array}$ \\
\hline
\end{tabular}

TBA is $300 \mathrm{mg}$ trenbolone acetate.

TBA + oestradiol is $140 \mathrm{mg}$ TBA plus $20 \mathrm{mg}$ oestradiol-1 $7 \beta$.

FCR is feed conversion ratio.

Values with the same superscripts are significantly different $(P<0.05)$ from each other.

The results for steers is from Heitzman, Chan et al. (1977) and for heifers from Heitzman \& Chan (1974).

Some recent studies (Heitzman, Harwood et al. 1977 ) have investigated whether anabolic agents could be successfully used at stages in the life of cattle other than the final fattening period. The results shown in Figure I demonstrate that the benefits gained from the anabolic agent during the first 3 months after implantation were not lost during later months. They also reported that reimplantation of steers 3 months after the first treatment produced additional increases in live weight gain compared with controls and those which had been implanted on only one occasion.

In Europe most beef is produced from intact bulls and there is an increasing use of this system in the USA and some in the UK. Anabolic agents are not generally used in bulls, mainly because the research trials are not at the development stage.

There is only a small production of veal in the UK but on the continent eight million veal calves are produced annually. Veal production is concentrated into intensive units and anabolic agents have been used successfully to increase productivity. The efficacy of different anabolic agents in the veal calf has been discussed by Van der Wal (1 976). The maximum increases in growth rate and FCE were obtained with combined preparations of androgens plus oestrogens and administered to both sexes at $2-3$ months of age.

\section{Use in sheep}

Sheep are a major source of meat, mainly through the production of fat lambs. Studies in France (Szumowski \& Grandadam, 1976) and Scotland (Coelho, J. F. G., Galbraith, H. \& Topps, J. H., unpublished results) suggested that combined preparations of androgen and oestrogen improved the growth rate and increased FCE in wether lambs compared with controls. The oestrogens, zeranol and hexoestrol are reported to show some improvements in growth rate and FCE but the responses and economic returns are not sufficient to encourage wide scale use.

\section{Use in pigs}

Anabolic agents have been used in pigs to try to improve the lean:fat tissue. 


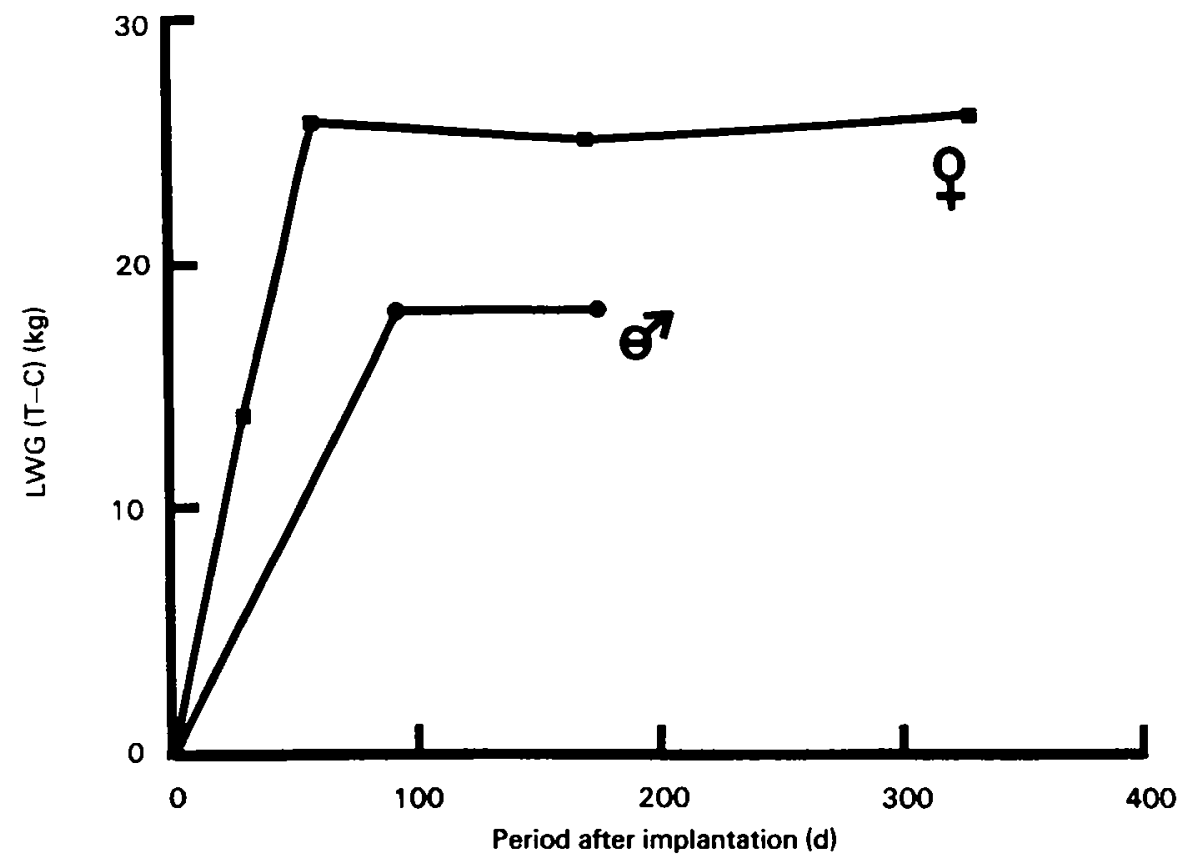

Fig. 1. Performance of cattle implanted with anabolic agents. The values are the differences at intervals after implantation between the average live weight gains (LWG) of treated animals (T) and controls (C). (_ ) heifers implanted with $300 \mathrm{mg}$ trenbolone acetate, 6 treated and 6 controls. acetate and $36 \mathrm{mg}$ hexoestrol, i I treated and i 1 controls.

Boars have higher rates of lean tissue growth than do females or castrates and therefore administration of testicular sex steroids to females and castrates should improve their carcase quality. Fowler (1976) suggested that maximum responses were obtained in female or castrate pigs when androgens and oestrogens are used in combination or when an androgenic steroid is used having some aromatization of the A-ring. Later studies (Fowler, V. R., Stockdale, C. L., Smart, R. I. \& Crofts, R. M. J., unpublished results) showed that oral administration to pigs of trenbolone acetate or methyl testosterone combined with ethynl oestradiol reduced fat tissue in castrate males but had little or no effect in females. Van Weerden \& Grandadam (1976) observed improvements in live weight gain, FCE, N-retention, carcase quality and lean tissue deposition in castrate male pigs receiving either implants of trenbolone acetate and oestradiol or oral administration of trenbolone acetate plus ethynl oestradiol. In farm practice implants are not yet used in pigs but some oral administration of androgen plus oestrogen is used. Improvement of performance of males is perhaps best achieved by allowing the animals to remain as intact boars.

\section{Use in poultry}

The anabolic agents, stilboestrol and hexoestrol, were used for the chemical caponizing of poultry. Nesheim (1976) reviewed the effectiveness of anabolic 
agents as growth promoters in poultry and concluded that androgens, oestrogens, thyroid active compounds and growth hormone are without effect. However, in a more recent study Ranaweera ('1977) showed that turkeys implanted with trenbolone acetate showed increased growth rate and FCE compared with controls.

Anabolic agents are being used on an increasing scale to improve growth rate and FCE in farm animals. The best results have been obtained in cattle, especially veal calves and beef steers. Some benefits are possible from their use in bulls, pigs, sheep, turkeys and trout but the investigations are still at the development stage.

Their use can be justified economically but the real benefit of wide scale use is the more efficient production of meat from limited feed inputs.

\section{REFERENCES}

Fowler, V. R. (1976). In Anabolic Agents in Animal Production. [F. C. Lu and J. Rendel, editors]. Suppl. V., 109.

Heitzman, R. J. (1976). In Anabolic Agents in Animal Production. [F. C. Lu and J. Rendel, editors]. Suppl. V., 89 .

Heitzman, R. J. \& Chan, K. H. (1974). Br. vet. J. 130, 532.

Heitzman, R. J., Chan, K. H. \& Hart, I. C. (1977). Br. vet. Y. 133, 62.

Heitzman, R. J., Harwood, D. J. \& Mallinson, C. B. (1977). F. Anim. Sci. Abstracts 6gth Annual Mtg. ASAS. 44 .

Nesheim, M. C. (1976). In Anabolic Agents in Animal Production. [F. C. Lu and J. Rendel, editors]. Suppl. V. I ro.

Ranaweera, P. (1977). The effects of trenbolone acetate in growing turkeys. Ph.D. Thesis, University of Cambridge.

Szumowski, P. \& Grandadam, J. A. (1976). Rec. Med. Vet. 152, 3 I I.

Van der Wal, P. (1976). In Anabolic Agents in Animal Production. [F. C. Lu and J. Rendel, editors!. Suppl. V., 60.

Van Weerden, E. J. \& Grandadam, J. A. (1976). In Anabolic Agents in Animal Production. [F. C. Lu and J. Rendel, editors]. Suppl. V., I I 5. 